\title{
Effect of lupeol from Vernonia glaberrima (Asteraceae) on pain and inflammation
}

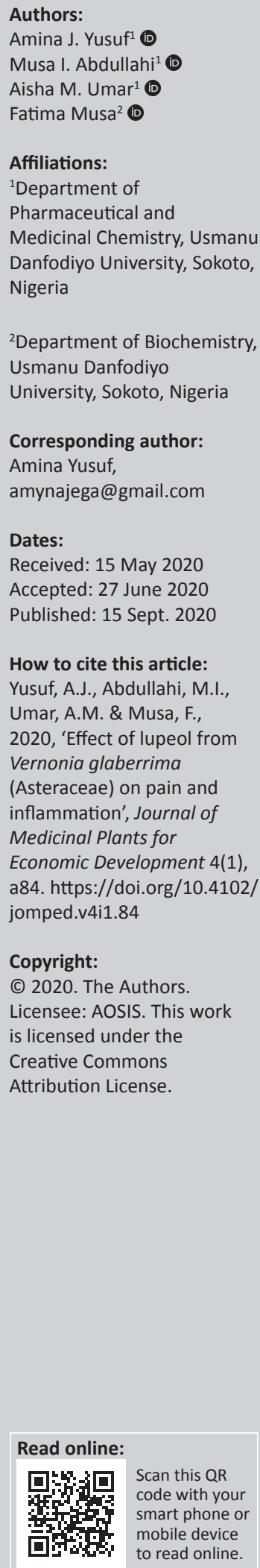

Background: Steroids have been reported to possess analgesic and anti-inflammatory activities, and Vernonia glaberrima also possesses analgesic and anti-inflammatory properties.

Aim: The aim of the study was to evaluate the effect of lupeol isolated from the n-hexane soluble fraction of the methanol leaf extract of $V$. glaberrima on pain and inflammation.

Method: Lupeol was re-isolated from the leaf of $V$. glaberrima by using chromatographic procedures; it was subjected to analgesic and anti-inflammatory studies by using acetic acidinduced writhing test in mice and formalin-induced pain and inflammation in rats, respectively. The intraperitoneal lethal dose $\left(\mathrm{LD}_{50}\right)$ of lupeol was determined by using Lorke's method.

Results: The results of the study showed that lupeol significantly $(p<0.05)$ decreased writhing response at doses $12.5 \mathrm{mg} / \mathrm{kg}, 25.0 \mathrm{mg} / \mathrm{kg}$ and $50.0 \mathrm{mg} / \mathrm{kg}$ corresponding to percentage inhibition of $83.60 \%, 83.63 \%$ and $80.02 \%$, respectively. This was higher than piroxicam, the standard drug $(73.8 \%)$, at $10 \mathrm{mg} / \mathrm{kg}$. The compound was also able to significantly $(p<0.05)$ reduce nociceptive response in both phases of the formalin test, and there was a remarkable reduction of oedema by the compound at the second, third and fourth hours. The median $\mathrm{LD}_{50}$ of the compound was estimated to be greater than $5000 \mathrm{mg} / \mathrm{kg}$.

Conclusion: The findings of this study indicated that lupeol from the leaf of $V$. glaberrima has good analgesic and anti-inflammatory activity that validates the ethnomedicinal use of the plant in the treatment of pain and inflammatory conditions.

Keywords: Vernonia glaberrima; lupeol; analgesic; anti-inflammatory; Lorke's method.

\section{Introduction}

Pain is the most common reason for a physician consultation in the most advanced countries (Conaghan 2012), and it is a major symptom in many medical conditions and significantly interferes with a person's quality of life and general functioning (Howland \& Mycek 2006). Analgesics are drugs that selectively relieve pain by acting in the central nervous system (CNS) or peripheral pain mechanisms without significantly altering consciousness (Howland \& Mycek 2006), but the drugs are accompanied by serious side effects such as euphoria, tolerance, respiratory depression, dependence, renal damage and gastrointestinal irritation to mention but a few (Emily \& Gari 2008; Howland \& Mycek 2006).

Vernonia glaberrima Welw. Ex.O. Hoffm., an erect shrub commonly known as bitter leaf of the red clay soil, belongs to the Asteraceae family; it is mostly found on hillside grassland of West and Central Africa (Burkill 1995). Vernonia glaberrima is commonly known as Shiwáákáár (shìwaákár)-ján-gágárií in Hausa-Northern Nigeria (Burkill 1995). The plant is used in ethnomedicine to treat different diseases such as malaria, migraine, diabetes, psora and dysmenorrhea (Burkill 1995). It is also employed in the treatment of pain, inflammation, vertigo, microbial infections, body pain, skin cancer and other skin-related disorders (Abdullahi et al. 2015a; Alhassan et al. 2018). Chemical investigations on the leaf of the plant have been confined to the isolation and characterisation of fatty acids, steroids and coumarins (Emily \& Gari 2008). Pharmacological studies ranging from anticancer, analgesic, anti-inflammatory, antimalarial, anti-diabetic, antimicrobial and antiviral activities have also been reported (Abdullahi et al. 2015b, 2015c, 2015d, 2017; Alhassan et al. 2018; Ananil et al. 2000). This study was conducted to evaluate the analgesic and anti-inflammatory activities of lupeol from V. glaberrima leaf. 


\section{Materials and methods}

\section{Study area}

All experiments were conducted in the Laboratory of Department of Pharmaceutical and Medicinal Chemistry in collaboration with Department of Pharmacology and Toxicology, Faculty of Pharmaceutical Sciences, Usmanu Danfodiyo University, Sokoto, Nigeria, from August 2017 to October 2017.

\section{Chemicals, reagents and standard drug}

All chemicals and reagents used in this study were of analytical grade. Piroxicam capsules (U.S.P, Yangzhou Pharmaceutical Co. LTD, Jiangsu, China) and pentazocine (injection BP; Alpha Laboratories LTD, India) were used.

\section{Isolation and structure elucidation of lupeol}

Lupeol (Figure 1) was re-isolated from the $n$-hexane fraction of the methanol leaf extract of $V$. glaberrima as white crystalline substance by using a combination of vacuum liquid and low-pressure column chromatography. The structure of the compound was established by using oneand two-dimensional nuclear magnetic resonance (NMR) spectroscopic analysis and by direct comparison of data obtained with those reported in the literature (Alhassan et al. 2018).

\section{Experimental animals}

Forty Swiss albino mice and 50 adult Wister rats of either sex weighing $18 \mathrm{~g}-22 \mathrm{~g}$ and $175 \mathrm{~g}-190 \mathrm{~g}$, respectively, were obtained from the Animal House Facility of the Department of Pharmacology and Toxicology, Usmanu Danfodiyo University, Sokoto, Nigeria. They were fed with laboratory diet and water ad libitum and maintained under standard conditions (12-h light and 12-h dark cycle) in propylene

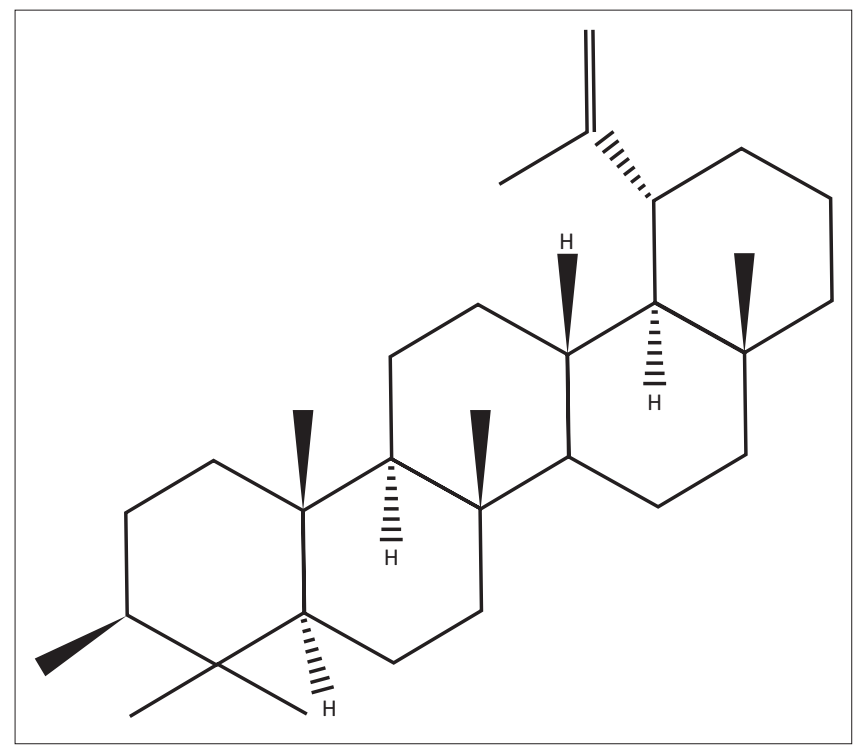

FIGURE 1: Structure of lupeol. cages at room temperature. All experimental procedures were approved by the Animal Right and Ethics Community of the University.

\section{Acute toxicity studies}

The intraperitoneal lethal dose $\left(\mathrm{LD}_{50}\right)$ of lupeol from $V$. glaberrima was determined according to the method described by Lorke (1983).

\section{Analgesic studies}

\section{Acetic acid-induced abdominal constrictions in mice}

The method described by Koster, Anderson and Beer (1959) was adopted; 25 albino mice were divided into five groups of five mice each. Group 1 was injected with $10 \mathrm{~mL} / \mathrm{kg}$ i.p. of normal saline (negative control). Groups 2-4 were injected i.p. with $12.5 \mathrm{mg} / \mathrm{kg}, 25 \mathrm{mg} / \mathrm{kg}$ and $50 \mathrm{mg} / \mathrm{kg}$ of lupeol, respectively, and group 5 received piroxicam $10 \mathrm{mg} / \mathrm{kg}$ (positive control). Thirty minutes later, each mouse was injected with $1 \mathrm{~mL} / \mathrm{kg}$ of aqueous solution of acetic acid $(0.6 \%)$. The number of abdominal constrictions for each mouse was counted 5 min after injection of acetic acid for a period of $10 \mathrm{~min}$. The percentage inhibition of abdominal constrictions was calculated by using the following formula:

$$
\text { Inhibition }(\%)=\frac{\begin{array}{c}
\text { Mean no. of writhes (negative control) }- \\
\text { Mean no. of writhes (test) }
\end{array}}{\text { Mean no. of writhes (negative control) }} \times 100 \text {. }
$$

[Eqn 1]

\section{Formalin test in rats}

The test was conducted in accordance with the method described by Dubuisson and Dennis (1977). Twenty-five rats were used. The rats were divided into five groups, each containing five rats. Group 1 was injected with $1 \mathrm{~mL} / \mathrm{kg}$ of normal saline i.p. (negative control). Groups 2-4 were injected i.p. with $12.5 \mathrm{mg} / \mathrm{kg}, 25 \mathrm{mg} / \mathrm{kg}$ and $50 \mathrm{mg} / \mathrm{kg}$ of lupeol, respectively, and group 5 was injected with pentazocine $10 \mathrm{mg} / \mathrm{kg}$ i.p. (positive control). Thirty minutes after this treatment, $50 \mu \mathrm{L}$ of a freshly prepared $2.5 \%$ solution of formalin was injected subcutaneously under the plantar surface of the left hind paw of each rat. The rats were placed individually in an observation chamber and monitored for $1 \mathrm{~h}$. The severity of pain response was recorded for each rat based on the following numerical scale: (0) rat walked or stood firmly on the injected paw; (1) the injected paw was favoured or partially elevated; (2) the injected paw was clearly lifted off the floor; (3) the rat licked, chewed or shook the injected paw. Anti-nociceptive effect was determined in two phases. The early phase (phase 1) was recorded during the first $5 \mathrm{~min}$, whereas the late phase (phase 2) was recorded during the last $45 \mathrm{~min}$ with a $10 \mathrm{~min}$ lag period in-between both phases (Dubuisson \& Dennis 1977). 


\section{Anti-inflammatory studies}

\section{Formalin-induced inflammation in rats}

Formaldehyde $2.5 \% \mathrm{v} / \mathrm{v}$ was used as inflammogen (Pateh et al. 2011). Rats were divided into five groups of five rats each. Thirty minutes before injection of $2.5 \% \mathrm{v} / \mathrm{v}$ formalin (50 $\mu \mathrm{L}$ volumes in the subplantar region of the left hind paw of the rat), the groups were treated i.p. as follows:

- Group 1 received $1 \mathrm{~mL}$ normal saline per $\mathrm{kg}$, as negative control.

- Groups 2, 3 and 4 received lupeol, at $12.5 \mathrm{mg} / \mathrm{kg}$, $25 \mathrm{mg} /$ $\mathrm{kg}$ and $50 \mathrm{mg} / \mathrm{kg}$, respectively.

- Group V received $10 \mathrm{mg}$ piroxicam per $\mathrm{kg}$, as positive control. The paw diameter $(\mathrm{cm})$ was measured by using Vernier calliper at an interval of $1 \mathrm{~h}$ for $4 \mathrm{~h}$.

\section{Statistical analysis}

All data were expressed as mean \pm standard error of mean (SEM). The mean values of control groups were compared with the mean values of treated groups by using one-way analysis of variance (ANOVA) followed by post hoc test by using the Statistical Package for Social Sciences (SPSS) software (version 22). Values were considered significant at $p<0.05$.

\section{Ethical consideration}

Ethical approval to conduct this study was received from the Animal Right and Ethics Community of the Usmanu Danfodiy University (UDUS/UREC/2020/001).

\section{Results \\ Toxicity studies}

The intraperitoneal $\mathrm{LD}_{50}$ of lupeol was found to be greater than $5000 \mathrm{mg} / \mathrm{kg}$ (Table 1). No death was recorded after administration of lupeol at the different doses in both phases.

\section{Analgesic studies}

\section{Acetic acid-induced writhing test}

Lupeol at the graded doses $(12.5 \mathrm{mg} / \mathrm{kg}, 25.0 \mathrm{mg} / \mathrm{kg}$ and $50 \mathrm{mg} / \mathrm{kg})$ significantly $(p<0.05)$ decreased the number of writhes in a dose-dependent manner. The reference drug, piroxicam (at $10 \mathrm{mg} / \mathrm{kg}$ ), exhibited a

TABLE 1: Median lethal dose $\left(\mathrm{LD}_{50}\right)$ of lupeol from Vernonia Glaberrima.

\begin{tabular}{lccc}
\hline Phase & Dose $(\mathrm{mg} / \mathrm{kg})$ & No. of mice used & Mortality \\
\hline First & 10 & 3 & $0 / 3$ \\
& 100 & 3 & $0 / 3$ \\
& 1000 & 3 & $0 / 3$ \\
Second & 1600 & 1 & $0 / 1$ \\
& 2900 & 1 & $0 / 1$ \\
& 5000 & 1 & $0 / 1$ \\
\hline
\end{tabular}

Note: The intraperitoneal $\mathrm{LD}_{50}$ of lupeol from $V$. glaberrima were calculated as follows: $\mathrm{LD}_{50}$ of lupeol $\leq 5000 \mathrm{mg} / \mathrm{kg}$ i.p. significant $(p<0.05)$ reduction of abdominal constrictions by $73.84 \%$ (Table 2 ).

\section{Formalin test in rats}

The pre-treatment of rats with lupeol significantly $(p<0.05)$ reduced nociceptive response induced by formalin in both phases (Table 3). There was a remarkable reduction of pain by the compound at the graded doses $(12.5 \mathrm{mg} / \mathrm{kg}$, $25.0 \mathrm{mg} / \mathrm{kg}$ and $50 \mathrm{mg} / \mathrm{kg}$ ) with $60.67 \%, 74.52 \%$ and $80.93 \%$ inhibition in the first phase, whereas in the second phase, the compound had $57.82 \%, 79.65 \%$ and $82.53 \%$ inhibition of pain; the standard drug, piroxicam (at $10 \mathrm{mg} /$ $\mathrm{kg}$ ), had $53.73 \%$ and $67.07 \%$ at both phases.

\section{Formalin-induced inflammation in rats}

Lupeol exhibited significant $(p<0.05)$ anti-inflammatory activity at the graded doses employed (Table 4$)$. The highest dose $(50 \mathrm{mg} / \mathrm{kg}$ ) was able to inhibit oedema induced by formalin with $47.62 \%, 49.35 \%, 52.86 \%$ and $58.21 \%$ at the first, second, third and fourth hours, respectively. The standard drug, piroxicam (10 mg/kg), had 31.75\%, 48.05\%, $47.14 \%$ and $50.75 \%$ inhibition.

TABLE 2: The effect of lupeol from Vernonia glaberrima on acetic acid-induced writhing in mice.

\begin{tabular}{lcc}
\hline Treatment $(\mathrm{mg} / \mathrm{kg})$ & Mean no. of writhes & \% inhibition \\
\hline Normal saline & $21.67 \pm 4.7$ & - \\
Lupeol (12.5) & $3.67 \pm 0.3^{*}$ & 83.60 \\
Lupeol (25.0) & $3.33 \pm 1.8^{*}$ & 83.63 \\
Lupeol (50.0) & $4.33 \pm 1.8^{*}$ & 80.02 \\
Piroxicam (10) & $5.67 \pm 3.7^{*}$ & 73.84 \\
\hline
\end{tabular}

Note: Each value represents mean \pm standard error of mean.

$*, p<0.05$ compared with normal saline (one-way analysis of variance); $n=5$.

TABLE 3: The effect of lupeol from Vernonia glaberrima on formalin-induced pain in rats.

\begin{tabular}{lcccc}
\hline \multicolumn{5}{c}{ Mean pain scores } \\
\hline Treatment (mg/kg) & First phase & \% inhibition & Second phase & $\%$ inhibition \\
\hline Normal saline & $5.77 \pm 0.1$ & - & $11.45 \pm 0.6$ & - \\
Lupeol (12.5) & $2.27 \pm 0.2^{*}$ & 60.67 & $4.83 \pm 0.1$ & 57.82 \\
Lupeol (25.0) & $1.47 \pm 0.2^{*}$ & 74.52 & $2.33 \pm 0.2^{*}$ & 79.65 \\
Lupeol (50.0) & $1.10 \pm 0.1 *$ & 80.93 & $2.00 \pm 0.1 *$ & 82.53 \\
Pentazocine (10) & $2.67 \pm 2.7 *$ & 53.73 & $3.77 \pm 2.3^{*}$ & 67.07 \\
\hline
\end{tabular}

Note: Each value represents mean \pm standard error of mean.

$*, p<0.05$ compared with normal saline (one-way analysis of variance); $n=5$.

TABLE 4: The effect of lupeol from Vernonia glaberrima on formaldehydeinduced inflammation in rats.

\begin{tabular}{lcccc}
\hline Treatment ( $\mathbf{m g} / \mathbf{k g})$ & \multicolumn{4}{c}{ Mean paw diameter (cm) (\% inhibition) } \\
\cline { 2 - 5 } & $\mathbf{1 ~ h}$ & $\mathbf{2 ~ h}$ & $\mathbf{3 ~ h}$ & $\mathbf{4 ~ h}$ \\
\hline Normal saline & $0.63 \pm 0.1$ & $0.77 \pm 0.2$ & $0.70 \pm 0.2$ & $0.67 \pm 0.1$ \\
Lupeol (12.5) & $0.57 \pm 0.0$ & $0.60 \pm 0.0$ & $0.53 \pm 0.1$ & $0.48 \pm 0.0$ \\
& $(9.52)$ & $(22.08)$ & $(24.29)$ & $(28.36)$ \\
Lupeol (25.0) & $0.40 \pm 0.2$ & $0.36 \pm 0.1^{*}$ & $0.33 \pm 0.0$ & $0.30 \pm 0.1^{*}$ \\
& $(36.51)$ & $(53.25)$ & $(52.86)$ & $(55.22)$ \\
Lupeol (50.0) & $0.33 \pm 0.2$ & $0.39 \pm 0.2^{*}$ & $0.33 \pm 0.0^{*}$ & $0.28 \pm 0.0 *$ \\
& $(47.62)$ & $(49.35)$ & $(52.86)$ & $(58.21)$ \\
Piroxicam (10) & $0.43 \pm 0.0$ & $0.40 \pm 0.0^{*}$ & $0.37 \pm 0.3$ & $0.33 \pm 0.1$ \\
& $(31.75)$ & $(48.05)$ & $(47.14)$ & $(50.75)^{*}$ \\
\hline
\end{tabular}

Note: Each value represents mean \pm standard error of mean.

$*, p<0.05$ compared with normal saline (one-way analysis of variance); $n=5$.

Values in parenthesis indicate percentage inhibition of inflammation. 


\section{Discussion}

Lupeol from $V$. glaberrima has showed significant $(p<0.05)$ analgesic and anti-inflammatory effects. The median $\mathrm{LD}_{50}$ of lupeol was found to be greater than $5000 \mathrm{mg} / \mathrm{kg}$, which indicates that the compound is generally non-toxic (Lorke 1983) (Table 1); previous studies conducted on the methanol leaf extract of $V$. glaberrima and the $n$-hexane soluble fraction showed a relatively lower $\mathrm{LD}_{50}$ values of $2154 \mathrm{mg} / \mathrm{kg}$ and $1265 \mathrm{mg} / \mathrm{kg}$, respectively (Abdullahi et al. 2015c, 2016). The possible explanation for this might be related to the presence of other secondary metabolites in the extract and fraction that contributes to the toxicity level of the plant.

Acetic acid-induced writhing test was used to assess the peripheral nociceptive effect of the lupeol (Gené et al. 1998). Writhings generated by administration of acetic acid in mice are because of profound pain of endogenous nature that recurs for a prolonged period of time. Because of irritant nature, these principles are also prone to induce lesions (Warden 2010). The intense pain is characterised by episodes of retraction of abdomen and stretching of hind limbs; the signals transmitted to central nervous system in response to pain because of irritation cause release of mediators such as prostaglandins, which contribute to the increased sensitivity to nociceptors (Buer 2014).

Lupeol at the graded doses significantly $(p<0.05)$ decreased writhing response at doses $12.5 \mathrm{mg} / \mathrm{kg}, 25 \mathrm{mg} / \mathrm{kg}$ and $50 \mathrm{mg} / \mathrm{kg}$ corresponding to percentage inhibition of $83.60 \%$, $83.63 \%$ and $80.02 \%$, respectively (Table 2 ). This was higher than piroxicam, the standard drug $(73.84 \%)$, at $10 \mathrm{mg} / \mathrm{kg}$. Pain inhibition by lupeol was significantly higher than the effect observed by the reference drug, piroxicam. The findings are in close agreement with what was reported for the n-hexane fraction of V. glaberrima (Abdullahi et al. 2016).

Formalin test in mice involves biphasic responses categorised into early phase (neurogenic pain) and the late phase (inflammatory reactions). Lupeol was able to significantly $(p<0.05)$ diminished the nociceptive response induced by formalin in a dose-dependent manner (Table 3); it exhibited $60.67 \%, 74.52 \%$ and $80.93 \%$ inhibition of pain at the graded doses $(12.5 \mathrm{mg} / \mathrm{kg}, 25 \mathrm{mg} / \mathrm{kg}$ and $50 \mathrm{mg} / \mathrm{kg})$ employed in the early phase; thus, the effect was higher than the standard drug piroxicam with $53.73 \%$ inhibition. A similar trend was observed for lupeol in the second phase; thus, the lowest dose exhibited the highest inhibition of pain. Studies have indicated that central acting drugs can inhibit both early and last phases, whereas peripheral acting drugs such as nonsteroidal anti-inflammatory drugs (NSAIDs) can only inhibit the last phase, which suggests that lupeol may possess central acting effects (Derardt et al. 1980; Maria et al. 1997).

Inflammation is a physiological body response against any harmful stimulus, leading to the activation of inflammatory cells that secrete increased amounts of nitric oxide (NO), nitric oxide synthase (iNOS), prostaglandin E2 (PGE2), cyclooxygenase-2 (COX-2) and cytokines (Derardt et al. 1980; Gepdiremen et al. 2005). To evaluate the effect of lupeol from $V$. glaberrima on inflammation, formalin test was used, which led to the development of oedema after injection of the inflammatory agent (formalin) in the left hind paw; this was accompanied by the release of inflammatory mediators; and lupeol significantly $(p<0.05)$ reduced the oedema level induced by formalin at the graded doses (Table 4$)$. The highest dose $(50 \mathrm{mg} / \mathrm{kg})$ indicated a higher inhibition of inflammation compared with the control with $49.35 \%, 52.86 \%$ and $58.21 \%$ inhibition at the second, third and fourth hours, respectively. The ability of lupeol to suppress the level of oedema suggests it to be a good anti-inflammatory agent (Gallo \& Sarachine 2009; Siddique \& Saleem 2011), and the mechanism of action of lupeol has been postulated to act via inhibition of tissue response to the induced nociception (Chen et al. 2012; Geetha \& Varalakshmi 2001), especially through the involvement of cytokines (De Lima et al. 2013). In addition, it has recently been shown that lupeol acetate acts as an anti-inflammatory agent by regulating tumour necrosis factor (TNF)-alpha and IL-2-specific mRNA, besides up-regulating the synthesis of IL-10 mRNA (Ashalatha et al. 2010).

\section{Conclusion}

Lupeol from $V$. glaberrima have showed significant analgesic and anti-inflammatory effects with the highest dose $(50 \mathrm{mg} / \mathrm{kg}$ ) having a strong effect. This further validates the ethnomedicinal claim of the use of the plant in the treatment of pain and inflammatory conditions. To the best of our knowledge, this is the first report that validated the analgesic and anti-inflammatory activities of lupeol from $V$. glaberrima leaf.

\section{Significance statement}

This study discovers the analgesic and anti-inflammatory effects of lupeol from $V$. glaberrima that can be beneficial to researchers and pharmaceutical industries in drug discovery and development. This study will help the researchers to uncover the critical areas of natural product research that many researchers were not able to explore. Thus, a new theory on natural product research may be arrived at.

\section{Acknowledgements}

We acknowledged the efforts of Mal. Abdullahi of Pharmacology and Toxicology \& Mal Hamza of Pharmaceutical \& Medicinal Chemistry, Usmanu Danfodiyo University, Sokoto, for assisting in animal handling and extraction.

\section{Competing interests}

The authors have declared that no competing interest exists.

\section{Authors' contributions}

M.I. Abdullahi performed research concept and design; A.M. Umar and A.J. Yusuf conducted the research and 
collected the data; A.M. Umar, A.J. Yusuf and F. Musa performed data analysis and interpretation; A.J. Yusuf wrote the article; and all authors were responsible for the critical revision and final approval of the article.

\section{Funding information}

This research received no specific grant from any funding agency in the public, commercial or not-for-profit sector.

\section{Data availability statement}

Data sharing is not applicable to this article as no new data were created or analysed in this stud.

\section{Disclaimer}

The views and opinions expressed in this article are those of the authors and do not necessarily reflect the official policy or position of any affiliated agency of the authors.

\section{References}

Abdullahi, M.I., Uba, A., Abdallahi, Y., Maxwell, O., Saifullahi, K., Alhasan, A.M. et al. 2015a, 'Phytochemical screening, acute toxicity study and evaluation of antidiabetic properties of the methanolic leaf extract of Vernonia glaberrima (Asteraceae)', Journal of Pharmaceutical, Chemical and Biological Sciences 3(2), 167-177. https://www.jpcbs.infolSSN-2348-7658.

Abdullahi, M.I., Uba, A., Umar, A., Alhasan, A.M., Yusuf, A.J., Yunusa, A. et al., 2015b, 'Studies on phytochemical constituents, toxicity, analgesic and anti-inflammatory activities of Vernonia glaberrima', Der Pharma Chemica 7(7), 273-278.

Abdullahi, M.I., Uba, A., Alebiosu, C.O., Alhasan, A.M., Yusuf, A.J., Mode, S. et al., 2015c, 'Antimicrobial properties of the methanol leaf extract of Vernonia glaberrima', African Journal of Pharmacy and Pharmacology 9(37), 915-918. https://doi.org/10.5897/AJPP2015.4421

Abdullahi, M.I., Uba, A., Yunusa, A., Kaita, A.H., Yaro, A.H., Yusuf, A.J. et al., 2015d, 'Evaluation of the anti-malarial effect of the methanolic leaf extract of Vernonia glaberrima (Asteraceae)', Journal of Pharmacy and Biological Sciences 10(1), glaberrim.

Abdullahi, M.I., Uba, A., Yusuf, A.J., Nasir, I., Muntaka, A., Alhasan, A.M. et al., 2016, 'Phytochemical analysis, analgesic and anti-inflammatory studies on the $n$-Hexane soluble fraction of Vernonia glaberrima', International Journal of Science for Global Sustainability 2(4), 16-23. ISSN: 2488-9229.

Abdullahi, M.I., Uba, A., Yusuf, A.J., Olowo-okere, A., Nasir, I., Muntaka, A. et al., 2017, 'Comparative antimicrobial activity of fractions of Vernonia glaberrima against selected human pathogens', Journal of Pharmacy and Bioresources 15(1), 169-174. https://doi.org/10.4314/jpb.v14i2.10

Alhassan, A.M., Ahmed, Q.U., Latif, J., Shah, S.A.A., Khan, A.A.Y.F., Sarian, M.N. et al., 2018, 'Phytoconstituents from Vernonia glaberrima Welw. Ex O. Hoffm. leaves and their cytotoxic activities on a panel of human cancer cell lines', South African Journal of Botany 116, 16-24. https://doi.org/10.1016/j.sajb.2018.02.391

Ananil, K., Hudson, J.B., de Souzal, C., Akpaganal, K., Tower, G.H.N., Amason, J.T. et al. 2000 , 'Investigation of medicinal plants of Togo for antiviral and antimicrobia activities', Pharmaceutical Microbiology 38, 40-45. https://doi.org/10.1076/13880209(200001)38:1;1-B;FT040
Ashalatha, K., Venkateswarlu, Y., Priya, A.M., Lalitha, P., Krishnaveni, M. \& Jayachandran, S., 2010, 'Anti-inflammatory potential of Decalepis hamiltonil (Wight and Arn) as evidenced by down regulation of pro-inflammatorycytokinesTNF-alpha and IL-2', Journal of Ethnopharmacology 130(1), 167-170. https://doi. org/10.1016/j.jep.2010.04.022

Buer, J.K., 2014, 'Origins and impact of the term NSAIDs', Inflammopharmacology 22(5), 263-267. https://doi.org/10.1007/s10787-014-0211-2

Burkill, M.H., 1995, The useful plants of tropical Africa, families J-L, vol. 3, pp. 229-230, Royal Botanic Gardens Kew, London.

Chen, Y.F., Ching, C., Wu, T.S., Wu, C.R., Hsieh, W.T. \& Tsai, H.Y., 2012, 'Balanophora spicata and lupeol acetate possess antinociceptive and anti-inflammatory activities in vivo and in vitro', Evidence-Based Complementary Alternative Medicine 2012(371273), 10. https://doi.org/10.1155/2012/371273

Conaghan, P.G., 2012, 'A turbulent decade for NSAIDs: Update on current concepts of classification, epidemiology, comparative efficacy and toxicity', Rheumatology International 32(6), 1491-1502. https://doi.org/10.1007/s00296-011-2263-6

De Lima, F.O., Alves, V., Filho, J.M.B., Da Silva, A.J.R.G., Rodrigues, L.C., Soares, M.B.P. et al., 2013, 'Antinociceptive effect of lupeol: Evidence for a role of cytokines
inhibition', Phytotherapy Research 27(10), 1557-1563. https://doi.org/10.1002/ ptr.4902

Derardt, R., Journey, S., Delevalcee, F. \& Falhout, M., 1980, 'Release of prostaglandins $E$ and $F$ in an algogenic reaction and its inhibition', European Journal of Pharmacology 61(1), 17-24. https://doi.org/10.1016/0014-2999(80)90377-5

Dubuisson, D. \& Dennis, S.R., 1977, 'The formalin test: A quantitative study of the analgesic effects of morphine, meperidine and brain stem stimulation in rats and cats', Pain 4, 161-174. https://doi.org/10.1016/0304-3959(77)90130-0

Emily, O.D. \& Gari, M.P., 2008, 'Opioid tolerance development: A pharmacokinetic/ pharmacodynamics perspective', American Association of Pharmaceutical Scientist Journal 10(4), 537-551. https://doi.org/10.1208/s12248-008-9056-1

Gallo, M.B.C. \& Sarachine, M.J., 2009, 'Biological activities of lupeol', Interanational Journal of Biomedical and Pharmaceutical Sciences 3(1), 46-66.

Geetha, T. \& Varalakshmi, P., 2001, 'Anti-inflammatory activity of lupeol and lupeol linoleate in rats', Journal of Ethnopharmacology 76(1), 77-80. https://doi.org/10. 1016/S0378-8741(01)00175-1

Gené, R.M., Segura, L., Adzet, T., Marin, E. \& Inglesias, J., 1998, 'Heterotheca inuloides: Anti- inflammatory and analgesic effects', Journal of Ethnopharmacology 60(2), 157-162. https://doi.org/10.1016/S0378-8741(97)00155-4

Gepdiremen, A., Mshvildadze, V., Suleyman, H. \& Elias, R., 2005, 'Acute antiinflammatory activity of four saponins isolated from ivy: Alphahederin hederasaponin- $C$, hederacolchiside- $E$ and hederacolchiside-F in carrageenan induced rat paw edema', Phytochemistry 12(6-7, 15), 440-444. https://doi.org/ 10.1016/j.phymed.2004.04.005

Howland, R.D. \& Mycek, M.J., 2006, 'Lippincott's illustration review: Pharmacology', R.A. Harvey \& P.C. Champe (eds.), pp. 157-168, Lippincott Williams and Wilkins publishers, London.

Koster, R., Anderson, M. \& Beer, E.J., 1959, 'Acetic acid for analgesic screening', Federation Proceeds 18, 412-416.

Lorke, D.A., 1983, 'New approach to practical acute toxicity testing', Archives of Toxicology 54(4), 275-287. https://doi.org/10.1007/BF01234480

Maria, E.N.G., Arthur, J., Da, S.E., Souccar, C. \& Antonio, J.L., 1997, 'Analgesic and antiinflammatory activities of the aqueous extract of Plantango major $L^{\prime}$ ', International Journal of Pharmacognosy 35(2), 99-104. https://doi.org/10.1076/phbi.35.2. Journal of

Pateh, U.U., Sule, I.M., Iliya, I., Harun, A.K., Yaro, A.H., Ambi, A.A. et al., 2011, 'Analgesic and anti-inflammatory activities of the methanolic extract of the rhizomes of Stylochiton lancifolius Pyre and Kotchy (Araceae) in rodents', Journal of Medicinal Plants Research 5(21), 5203-5207.

Siddique, H.R.S. \& Saleem, M., 2011, 'Beneficial health effects of lupeol triterpenes: A review of preclinical studies', Life Sciences 88(7-8), 285-293. https://doi.org/10. 1016/j.lfs.2010.11.020

Warden, S.J., 2010, 'Prophylactic use of NSAIDs by athletes: A risk/benefit assessment', The Physician and Sports Medicine 38(1), 132-138. https://doi.org/10.3810/ psm.2010.04.1770 